\title{
Global health training and postgraduate medical education in Australia: the case for greater integration
}

Rob D Mitchell MB BS(Hons), BMedSc(Hons) Registrar

Jennifer C Jamieson MB BS, BBiomedSci Emergency Registrar

Jake Parker

BSc, MB BS,

MSc(ClinPhysiol), Communicable Diseases Resident Medical Officer

Fred B Hersch BSc, MB BS(Hons), MPH Honorary Associate

Zoe Wainer BM BS, BHSC, PhD Candidate

A Rob Moodie MB BS, MPH Professor

1 Emergency Department Townsville Hospital Townsville, QLD.

2 Médecins Sans Frontières Trauma Centre, Kunduz, Afghanistan

3 Kimberley Population Health Unit, Broome, WA

4 Menzies Centre fo Health Policy, Sydney Medical School University of Sydney, Sydney, NSW.

5 Department of Surgery, University of Melbourne and St Vincent's Hospital Melbourne, VIC.

6 School of Population Health, University of Melbourne, Melbourne, VIC

mitchell.rob@me.com

doi: 10.5694/mjal2.11611

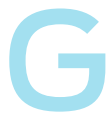

lobal health $(\mathrm{GH})$ is now firmly entrenched as an academic discipline in its own right. Defined as an area for study, research and practice that places a priority on improving health and achieving health equity for all people worldwide, it emphasises transnational health issues, determinants and solutions; involves many disciplines between and beyond the health sciences; and synthesises population-based prevention with individuallevel care. ${ }^{1}$

This article, written from the trainee perspective, considers the relevance of global heath experiences to postgraduate medical education systems in Australia. It examines the risks and benefits of vocational trainee exposure to international rotations in resource-poor settings and makes recommendations for enhanced integration of $\mathrm{GH}$ with specialty education programs.

\section{Global health training}

Recognition that doctors engaged in $\mathrm{GH}$ practice require a skill set beyond that traditionally incorporated into medical curricula has given rise to the concept of GH training. ${ }^{2,3}$ The groundswell of activity in this area has occurred in North America, where education in GH is increasingly integrated with medical school and postgraduate training programs. Although there is significant variation in the way GH training is delivered, curricula tend to focus heavily on health equity concepts and generally encourage international fieldwork. ${ }^{2-5}$ In some institutions, fellowship programs have been developed to allow senior trainees to acquire more advanced skills. ${ }^{6,7}$

In response to this growth, a comprehensive guidebook for the incorporation of GH training into residency programs has been published. ${ }^{4}$ Ethical guidelines for overseas rotations have also been produced, including statements by the Working Group on Ethics Guidelines for Global Health Training and trainee associations. ${ }^{5,8}$ These recognise the ethical complexities involved in international placements. 9,10

This evolution is in keeping with a broader movement towards greater social accountability in medical education. ${ }^{11}$ Consistent with this, a 2010 Lancet commission called for additional emphasis on transformative and interdependent learning in order to produce health professionals who are equipped to face the global challenges of the 21st century. ${ }^{12}$

To a large extent, the expansion in GH training has been driven by a well documented demand from trainees. For

\section{Summar \\ - Global health (GH) training is well established overseas (particularly in North America) and reflects an increasing focus on social accountability in medical education. \\ - Despite significant interest among trainees, GH is poorly integrated with specialty training programs in Australia. \\ - While there are numerous benefits from international rotations in resource-poor settings, there are also risks to the host community, trainee and training provider. \\ - Safe and effective placements rely on firm ethical foundations as well as strong and durable partnerships between Australian and overseas health services, educational institutions and $\mathrm{GH}$ agencies. \\ - More formal systems of GH training in Australia have the potential to produce fellows with the skills and knowledge necessary to engage in regional health challenges in a global context.}

example, a 2007 study of 724 surgical residents in the United States found that $92 \%$ were interested in undertaking an international clinical elective and $82 \%$ would prioritise this over other opportunities. ${ }^{13}$ In Canada, a recent survey of 1735 junior doctors identified that $43 \%$ had undertaken or planned to undertake GH activities. ${ }^{14}$

\section{Australian experience}

The extent to which Australian graduates are attracted to GH training has not been quantified but there is surrogate evidence of interest. Trainees are increasingly accessing GH learning and networking activities, including Global Health Gateway (an online resource: http://www.globalhealthgateway.org.au), the Global Ideas Forum (a conference for early career health professionals: http:// www.globalideasforum.org) and Global Health Drinks (an informal experience-sharing forum in Sydney: http:// www.globalhealthdrinks.org). The development of $A$ guide to working abroad for Australian medical students and junior doctors, published as an eSupplement to this Journal, is also indicative of the interest in the area. ${ }^{15}$

At the undergraduate level, one study has suggested that over $90 \%$ of students believe that GH should be a component of medical school programs, and the number of attendees at the annual Australian Medical Students' Association Global Health Conference continues to rise. ${ }^{16}$ Membership of university GH groups is also increasing. ${ }^{17}$

Despite the level of interest, GH training is poorly integrated with postgraduate medical education systems in 


\begin{tabular}{|c|c|c|}
\hline Stakeholder & Benefit & Examples \\
\hline \multirow[t]{2}{*}{ Trainee } & Personal development & $\begin{array}{l}\text { Improved cultural safety; enhanced personal awareness; opportunities for leadership; appreciation of the } \\
\text { complexities of enacting change as a visitor }\end{array}$ \\
\hline & Professional development & $\begin{array}{l}\text { Exposure to different pathologies; refinement of diagnostic skills; appreciation of unique challenges } \\
\text { within different health care systems; rationalisation of health care resources; development of a } \\
\text { population and community health perspective }\end{array}$ \\
\hline \multirow[t]{3}{*}{$\begin{array}{l}\text { Training institution } \\
\text { and/or health service }\end{array}$} & Enhanced clinical practice & $\begin{array}{l}\text { New skills and knowledge sets that can be applied locally; systems improvement based on experience } \\
\text { abroad; greater exposure to interprofessional training and practice }\end{array}$ \\
\hline & Recruitment and retention & Attract and retain trainees with an interest in global health \\
\hline & Mutually beneficial partnerships & Establish international exchanges, offering new training, clinical improvement and research opportunities \\
\hline \multirow[t]{2}{*}{ Australian community } & Improved standards of health care & $\begin{array}{l}\text { Complex health care delivered by clinicians with improved clinical, cultural and sociopolitical awareness; } \\
\text { enhanced performance based on international knowledge and experience; clinicians experienced in } \\
\text { generalist medicine }\end{array}$ \\
\hline & More equitable health care & Service delivery targeted at disadvantaged populations \\
\hline \multirow[t]{3}{*}{ Host community } & Education and training & $\begin{array}{l}\text { Clinical and non-clinical education delivered by visiting doctors; knowledge exchange between trainees; } \\
\text { resources for enhanced training and supervision provided by Australian partners; opportunities for local } \\
\text { graduates to undertake short- and medium-term reciprocal placements in affiliated Australian } \\
\text { institutions }\end{array}$ \\
\hline & Research capacity & Enhanced capabilities based on mutually beneficial partnerships \\
\hline & Systems enhancement & $\begin{array}{l}\text { Systems improvement based on Australian experience; additional workforce in the form of visiting } \\
\text { trainees; development of long-term, mutually beneficial relationships }\end{array}$ \\
\hline
\end{tabular}

Australia. Only recently has one college faculty drafted a specific curriculum to prepare fellows for GH practice. ${ }^{18}$ Key themes include reflective practice, cultural competency, health systems strengthening, community development, aid effectiveness and GH advocacy. While pathways to international work in other disciplines are relatively informal, the requisite skill sets are increasingly being described. ${ }^{19}$

Among colleges, mechanisms for determining if overseas rotations can be accredited towards fellowship are variable. ${ }^{15}$ Some have relatively well defined pathways the Australasian College for Emergency Medicine, for instance, has created a specific option for trainees to undertake accredited training in a resource-poor environment with arrangements for remote supervision. ${ }^{20}$ Certain other colleges, including the Royal Australasian College of Physicians, have prospective approval processes for senior registrars wishing to undertake overseas placements. ${ }^{15}$

Although there are now several university-affiliated GH institutes, these are not well integrated with clinical training programs. As a marker of this, growing numbers of medical graduates are enrolling in relevant postgraduate courses, such as Masters of Public Health. These increasingly include a focus on health systems in developing countries. $^{21}$

In the absence of formal arrangements, access to GH experiences is limited by a number of factors, including a lack of recognition from educational providers, suboptimal supervision arrangements, limited access to cultural competency training, competing training commitments, family responsibilities, loss of income and safety concerns. ${ }^{2,14,15}$ As a result, vocational trainees interested in working abroad tend to do so outside formal training programs and often through non-governmental organisations or volunteer placement agencies. One example is Médecins Sans Frontières Australia, which in 2012 dispatched 44 doctors (and many other health professionals) to international field settings; a majority of these were non-specialists (Sophie McNamara, Communications Officer, Médecins
Sans Frontières Australia, personal communication, February 2013).

\section{Benefits and risks}

Reports of Australian trainees undertaking accredited training in overseas settings suggest that GH experiences can feasibly be undertaken as part of specialty education programs. ${ }^{15,22,23}$ While some aspects of GH education can be undertaken locally, many trainees will eventually seek international clinical experiences. The benefits of rotations in resource-poor settings are summarised in Box 1 . Similar advantages have been described internationally. $2,5,24$

Several published examples illustrate how GH rotations can work in practice. ${ }^{15,22,23}$ Characteristically, these include service delivery and education components based on mutually agreed learning and development objectives. For instance, a recently described placement for Australasian College for Emergency Medicine trainees in Papua New Guinea includes both a clinical role in a regional emergency department and a teaching appointment at a local university. 22,23

$\mathrm{GH}$ training based on sound principles has the potential to provide rewarding training experiences for Australian trainees, broker relationships between Australian and overseas health services and education providers, and build health care capacity in host communities. The establishment of international academic partnerships would also lend itself to enhanced regional research capabilities. Together, these developments would allow Australia to increase its practical contribution towards emerging $\mathrm{GH}$ challenges (such as chronic disease in the Asia-Pacific region) and help answer the call for greater leadership in the discipline. ${ }^{25}$

International clinical experiences also carry the potential for harm to the trainee, the training institution and the host community (Box 2). 2,5,9,10,24 These risks are similar to those associated with short-term medical missions undertaken outside of mature and sustainable partnerships. ${ }^{26}$ 


\begin{tabular}{|c|c|c|}
\hline Stakeholder & Risk & Examples \\
\hline \multirow[t]{3}{*}{ Trainee } & Suboptimal training & Inadequate supervision or educational support \\
\hline & Physical and mental health & $\begin{array}{l}\text { Communicable diseases; volatile environments; limited support networks and pastoral care; insufficient } \\
\text { reflection and evaluation on completion of placement }\end{array}$ \\
\hline & Financial stress & Loss of income and entitlements; travel expenses \\
\hline \multirow{2}{*}{$\begin{array}{l}\text { Training institution } \\
\text { and/or health service }\end{array}$} & Financial loss & Loss of setup costs if training partnership fails \\
\hline & Liability & Potential legal proceedings; damage to reputation \\
\hline \multirow[t]{4}{*}{ Host community } & Deviation from local priorities & $\begin{array}{l}\text { Attention placed on health priorities not endorsed by the local community; emphasis put on Western } \\
\text { models of health care that may not be appropriate for developing settings; focus potentially shifted away } \\
\text { from generalist medicine }\end{array}$ \\
\hline & Inequitable partnership & Lack of involvement in decision making; imbalance in cost; attention deviated from service delivery \\
\hline & Unacceptable and unethical practices & $\begin{array}{l}\text { Unsafe practice as a result of inexperience, inadequate supervision and unfamiliarity; culturally } \\
\text { inappropriate practices resulting in psychological harm to patients }\end{array}$ \\
\hline & Human capital displacement & $\begin{array}{l}\text { Displacement of local trainees; trained local health workers emigrating to Australia; disincentive to invest } \\
\text { in a local workforce }\end{array}$ \\
\hline
\end{tabular}

The negative effects of "voluntourism" have been well described. ${ }^{26,27}$

Host communities are vulnerable; however, implementation of risk management strategies and observance of ethical guidelines should greatly ameliorate the potential for harm., 5,24 Any arrangement where one party is exploited for the benefit of another would be unacceptable.

\section{Towards greater integration}

Notwithstanding the risks, the demand from trainees and educators for $\mathrm{GH}$ experiences means that the establishment of formal GH training pathways in Australia warrants greater consideration. This would align postgraduate training with the broader movement towards social accountability in medical education as well as Australia's broader aid and foreign policy objectives. Similar calls have recently been made in the United Kingdom. ${ }^{28}$

Necessary steps as part of this evolution include:

- attainment of better-quality data on models currently in operation and the extent of interest among trainees;

- development of guidelines for Australian vocational trainees undertaking placements abroad, which could be supplemented by specialty- and placement-specific advice; - integration and mainstreaming of GH education into postgraduate training curricula;

- incorporation of GH training into medical education conferences, to highlight best practice and encourage the development of evidence-based programs;

- design, support and evaluation of opportunities for vocational trainees to undertake rotations abroad that are safe, effective and ethically defensible, in part because they are incorporated into mature bilateral relationships and accredited by the relevant training body; and

- development of mutually beneficial and enduring partnerships between Australian and overseas health services, training institutions and $\mathrm{GH}$ agencies, underpinned by a commitment to academic collaboration and the exchange of knowledge and experience.

Although no central body has the capacity or authority to manage this process, incremental change should be achievable with collaboration between trainees, health services and education providers.
Experience from overseas suggests that development of effective $\mathrm{GH}$ training systems is likely to occur in an iterative fashion, with qualified institutions that have mature international partnerships leading by example. Medical colleges have a key role to play, drawing on the experience of international affiliates, academic institutes and volunteer deployment agencies.

Fortunately, there is no shortage of guidance to inform the process. ${ }^{3-5,9,15,24,29}$ Particularly relevant are previously defined competencies for Australian health professionals working in international health, including in technical, cultural and interpersonal domains. ${ }^{29}$ Ethical principles for Australian junior doctors practising in overseas settings have also been published and provide a platform for more substantive guidelines. ${ }^{18}$

More formal systems of GH training in Australia have the potential to create a cohort of doctors with the skills and knowledge necessary to engage in regional health challenges in a global context. Despite the complexity of developing safe and effective programs based on strong and durable international partnerships, the case for change is compelling.

Competing interests: No relevant disclosures.

Provenance: Not commissioned; externally peer reviewed.

1 Koplan JP, Bond TC, Merson MH, et al; Consortium of Universities for Global Health Executive Board. Towards a common definition of global health. Lancet 2009; 373: 1993-1995.

2 Drain PK, Holmes KK, Skeff KM, et al. Global health training and international clinical rotations during residency: current status, needs, and opportunities. Acad Med 2009; 84: 320-325.

3 Battat R, Seidman G, Chadi N, et al. Global health competencies and approaches in medical education: a literature review. BMC Med Educ 2010; 10: 94.

4 Chase J, Evert J, editors. Global health training in graduate medical education: a guidebook. 2nd ed. San Francisco: Global Health Education Consortium, 2011. http://globalhealtheducation.org/resources OLD/Documents/ Both\%20Students\%20And\%20Faculty/GH_Training_in_GME_Guidebook_ 2Ed.pdf (accessed Mar 2013).

5 Crump JA, Sugarman J; the Working Group on Ethics Guidelines for Global Health Training (WEIGHT). Ethics and best practice guidelines for training experiences in global health. Am J Trop Med Hyg 2010; 83: 1178-1182.

6 University of California, San Franciso, Division of Hospital Medicine. Global Health-Hospital Medicine Fellowship. http://hospitalmedicine.ucsf.edu/ fellowship/globalhealth.html (accessed Sep 2012).

7 Harvard University Global Health Institute. Global Health Leadership Fellows, Massachusetts General Hospital. http://globalhealth.harvard.edu/org/globalhealth-leadership-fellows-massachusetts-general-hospital (accessed Feb 2013). 
8 Canadian Association of Internes and Residents. CAIR guidelines for resident physician participation in global health elective placements. Ottawa: CAIR, 2011. http://www.cair.ca/u/elibrary/CAIR\%20Guidelines\%20for\%20global \%20health\%20elective\%20placements.pdf (accessed Mar 2013).

9 Reisch RA. International service learning programs: ethical issues and recommendations. Dev World Bioeth 2011; 11: 93-98.

10 Shah S, Wu T. The medical student global health experience: professionalism and ethical implications. J Med Ethics 2008; 34: 375-378.

11 Murray RB, Larkins S, Russell $H$, et al. Medical schools as agents of change: socially accountable medical education. Med J Aust 2012; 196: 653.

12 Frenk J, Chen L, Bhutta ZA, et al. Health professionals for a new century: transforming education to strengthen health systems in an interdependent world. Lancet 2010; 376: 1923-1958.

13 Powell AC, Casey K, Liewehr DJ, et al. Results of a national survey of surgical resident interest in international experience, electives, and volunteerism. J Am Coll Surg 2009; 208: 304-312.

14 Bourque JM. Global health in postgraduate medical education: results of a national survey and a literature review [abstract]. Presented at the Transcending borders towards global health conference; 2012 Apr 27-29; London, UK. http://www.transcendingborders.ca/pdf/abstracts.pdf (accessed Mar 2013).

15 Parker J, Mitchell R, Mansfield S, et al. A guide to working abroad for medical students and junior doctors. Med J Aust 2011; 194: eSI-S95.

16 Roberts-Thomson R, Smith T, Mitchell R. Importance of global health in undergraduate curricula - the Australian medical student perspective [abstract]. Presented at the Association for Medical Education in Europe conference; 2010 Sep 4-8; Glasgow, UK. http://www.amee.org/documents/ AMEE\%202010\%20Abstract\%20book.pdf (accessed Mar 2013).

17 Fox GJ, Thompson JE, Bourke VC, Moloney G. Medical students, medical schools and international health. Med J Aust 2007; 187: 536-539.

18 Australasian Faculty of Public Health Medicine. Draft AFPHM Curriculum to prepare Fellows for global health practice. AFPHM eBulletin 2011; 4 Nov: 3.
19 Sistenich V. International emergency medicine: how to train for it. Emerg Med Australas 2012; 24: 435-441.

20 Curry C. Editorial. Newsletter of the International Emergency Medicine Special Interest Group of the Australasian College for Emergency Medicine 2010; 6: 1-2. http://www.acem.org.au/media/international/IEMSIG_Newsletter December_10.pdf (accessed Mar 2013).

21 Negin J, Martiniuk A, Morgan C, et al. Building health systems capacity in global health graduate programs: reflections from Australian educators. BMC Int Health Hum Rights 2012; 12: 14.

22 Dening K. An advanced trainee's adventure! Emergency medicine in Madang, Papua New Guinea. Newsletter of the International Emergency Medicine Special Interest Group of the Australasian College for Emergency Medicine 2010; 6:3-4. http://www.acem.org.au/media/international/IEMSIG_Newsletter_ December_10.pdf (accessed Mar 2013).

23 Phillips GA, Hendrie J, Atua V, Manineng C. Capacity building in emergency care: an example from Madang, Papua New Guinea. Emerg Med Australas 2012; 24: 547-542.

24 Vermund $\mathrm{SH}$, Audet CM, Martin $\mathrm{MH}$, Heimburger $\mathrm{DH}$. Training programmes in global health. BMJ 2010; 341: c6860.

25 Leeder SR, Raymond SU, Greenberg HM. The need for leadership in global health. Med J Aust 2007; 187: 532-535.

26 Martiniuk AL, Manouchehrian M, Negin JA, Zwi AB. Brain gains: a literature review of medical missions to low and middle-income countries. BMC Health Serv Res 2012; 12: 134

27 Snyder J, Dharamsi S, Crooks VA. Fly-by medical care: conceptualizing the global and local social responsibilities of medical tourists and physician voluntourists. Global Health 2011; 7: 6.

28 Hall J, Brown CS, Pettigrew L, et al. Global health in UK postgraduate medical training. Lancet 2012; 380: 728-729.

29 Akbar H, Hill PS, Rotem A, et al. Identifying competencies for Australian health professionals working in international health. Asia Pac J Public Health 2005; 17: 99-103.

\section{Stamps of greatness}

\section{Dominique Jean Larrey (1766-1842)}

LARREY was born on 8 July 1766, in Beaudéan, in the Pyrenees, France. He was orphaned at an early age and was raised by his uncle, who was the chief surgeon at the Toulouse Hospital and who introduced him to medicine.

Larrey graduated from the University of Paris in 1787 to become a naval surgeon, narrowly escaping shipwreck off the coast of Newfoundland.

On his return to France, he witnessed the French Revolution, many casualties of which ended up as his patients.

In 1792, he served as a military surgeon in the Army of the Rhine, where he first organised his ambulance volantes, or flying ambulances - two-wheeled, horse-drawn carts for rapid evacuation of casualties.

In 1794, Larrey became chief surgeon of the Army of Italy, where he met Napoleon Bonaparte. He served under Napoleon in Italy, Egypt and Austria. In a memoir published in Cairo in 1802, he was the first to point out the contagious nature of Egyptian ophthalmia (granular conjunctivitis).

In 1804, Larrey was decorated with the Legion of Honour, appointed inspector of hospitals and chief surgeon of the royal guard, and made a baron.

He also accompanied Napoleon to Moscow, but was later seriously wounded at Waterloo and left for dead. Captured and facing execution, he was recognised by a Prussian surgeon who successfully pleaded for Larrey's life with Field Marshal Blucher. Larrey's life was spared partly because he had saved the life of
Blucher's son when the latter was taken prisoner by the French in an earlier skirmish.

He was surgeon-in-chief to the Grand Armée, taking part in 60 battles and 400 engagements. He was wounded three times and performed as many as 200 amputations within 24 hours at the Battle of Borodino. He later became a professor at the military hospital in Val-de-Grâce. Like Ambroise Paré, he was adored by his comrades for his good nature, courage and humanity.

Napoleon said of him that he was "... the most virtuous man that I have ever known" and left Larrey 100000 francs in his will. Larrey's best-known work is his four-volume Memoirs of military medicine, which contains the first recorded account of trench foot (1812).

He was the first to successfully amputate at the hip joint (1803). He was aware of the principle of wound debridement long before Gray (1915) and Lemaitre (1917-1918), and of the use of refrigeration as an aid to amputations.

His name is associated with "Larrey's operation", or the amputation of the shoulder joint, and with "Larrey's bandage".

One of the world's most renowned surgeons, Larrey died on 24 July 1842, in Lyons, France, and was postally honoured by France in 1964 on a Red Cross Fund stamp. 